\title{
PENGENDALIAN KUALITAS PROSES PRODUKSI KOPI ARABIKA PADA UD. CIPTA LESTARI DI DESA PUJUNGAN
}

\author{
I Gusti Ayu Andika Harum Sari ${ }^{1}$ \\ Gede Mertha Sudiartha ${ }^{2}$ \\ ${ }^{1,2}$ Fakultas Ekonomi dan Bisnis Universitas Udayana (Unud), Bali, Indonesia \\ e-mail: andikaharumsari@yahoo.com
}

\begin{abstract}
ABSTRAK
Statistical Quality Control merupakan suatu alat yang digunakan untuk mengukur seberapa optimalnya pengendalian kualitas yang dilakukan pada perusahaan. Penelitian ini dilakukan pada perusahaan UD. Cipta Lestari yang bergerak dibidang manufaktur. Penelitian ini merupakan salah satu bentuk penelitian deskriptif dengan pendekatan kuantitatif. Adapun data yang dipergunakan dalam penelitian ini merupakan data jumlah produk kopi arabika cacat pada bulan Agustus s.d bulan September 2018. Analisis data dilakukan dengan menggunakan teknikStatistical Quality Control,Check Sheet, P-chart, Quality Cost danFishbone Diagram. Hasil analisis data dengan menggunakan P-chart menunjukkan bahwa jumlah kecacatan produk kopi arabika masih berada dalam batas kendali yang berarti pengendalian kualitas di perusahaan sudah baik, sedangkan apabila dilihat dari analisis biaya kualitas perusahaan pada tahun 2018, biaya kualitas aktual yang harus dikelurkan perusahaan sejumlah Rp. 6,973,783.78 lebih besar bila dibandingkan dengan biaya kualitas optimum perusahaan yaitu Rp.6,708,203.94 hal ini dapat diartikan bahwa pengendalian kualitas proses produksi yang dilakukan pada perusahaan masih belum dapat mencapai tingkat optimal. Untuk dapat mencapai tingkat optimal perusahaan harus melakukan perbaikan pada empat faktor utama yang mempengaruhi jumlah produk cacat, yaitu faktor tenaga kerja, mesin, metode serta faktor lingkungan.
\end{abstract}

Kata kunci : pengendalian kualitas, statistical quality control, biaya kualitas

\begin{abstract}
Quality Control Statistics is a tool used to measure the optimization of quality control carried out on the company. This research was conducted at UD. Cipta Lestari engaged in manufacturing. This research is one form of descriptive research with a quantitative approach. The data used in this study are data on the number of defective arabica coffee products in August to September 2018. Data analysis was performed using Statistical Quality Control, Check Sheet, P-chart, Quality Cost and Fishbone Diagram techniques. The results of the analysis using the P-chart show that the number of defects of Arabica coffee products is still in a very good quality limit, while viewed from the component to measure the company's quality costs in 2018, the quality of actual costs has been released by the company. 6,973,783.78 is greater than the optimal quality cost of the company, which is Rp.6,708,203.94 this can be interpreted that changes in the quality of processes carried out on the company still cannot reach the optimal level. To be able to reach the optimal level the company must make improvements to the four main factors that affect the number of defects, namely labor, machinery, methods and environmental factors.
\end{abstract}

Keywords: quality control, statistical quality control, quality cost 
I Gusti Ayu Andika Harum Sari dan Gede Mertha Sudiartha, Pengendalian Kualitas Pro...

\section{PENDAHULUAN}

Kualitas kini telah menjadi pertimbangan utama bagi seorang konsumenalam memenuhi kebutuhannya, hal ini karena pada era globalisasi seperti sekarang ini jumlah produk sejenis yang beredar di pasaran sangat banyak dan rata-rata produk tersebut memiliki harga dan fungsi dasar yang sama. Jadi, satu-satunya dimensi yang dapat digunakan untuk membedakan produk sejenis tersebut adalah kualitas produk tersebut. Untuk dapat bertahan di pasar yang kompetitif, peningkatan kualitas dan produktivitas proses atau produk merupakan suatu keharusan bagi setiap perusahaan (Runtuwene, 2017). Para pemilik bisnis tanpa terkecuali kini berlomba-lomba untuk dapat menarik perhatian konsumen dengan cara memproduksi atau menghasilkan suatu produk yang berkualitas (Marire, 2014). Produk yang berkualitas baik akan mencerminkan keberhasilan suatu perusahaan dalam memenuhi harapan konsumen, yang tentunya akan membawa citra baik bagi perusahaan (Indriastitu, 2017).

Kualitas menurut Heizer dan Render (2015:222) adalah keseluruhan fitur dan juga karakteristik sebuah barang atau jasa yang menggunakan kemampuannya untuk memenuhi kebutuhan yang tertulis maupun tersirat. Untuk dapat menghasilkan produk yang berkualitas, perusahaan harus merencanakan dan mengendalikan dengan baik proses produksi produk tersebut (Weckenmann, 2015). Kegiatan pengendalian kualitas akan membantu perusahaan dalam menghasilkan produk yang bermutu baik, meningkatkan mutu produk secara terus-menerus, dan dapat menekan biaya produksi (Kemit, 2016). 
Pengendalian kualitas proses produksi merupakan kegiatan perencanaan dan pengawasan proses produksi mulai dari bahan mentah belum diolah sama sekali, hingga bahan tersebut berubah menjadi produk jadi yang sesuai dengan standar perusahaan. Apabila produk yang diproduksi oleh perusahaan tidak sesuai dengan standar yang telah ditetapkan, maka produk tersebut masuk ke dalam kelompok produk cacat. Produk cacat tersebut nantinya akan dianalisis penyebab kecacatannya oleh perusahaan, dan nantinya hasil analisis tersebut akan digunakan sebagai pegangan sekaligus pembelajaran agar nantinya perusahaan tidak melakukan kesalahan yang sama dan sebisa mungkin menghindari kesalahan tersebut agar proses produksi berjalan dengan lebih baik dan tentunya lebih berkualitas.

Pengendalian kualitas proses produksi merupakan kegiatan perencanaan dan pengawasan proses produksi mulai dari bahan mentah belum diolah sama sekali, hingga bahan tersebut berubah menjadi produk jadi yang sesuai dengan standar yang telah ditetapkan perusahaan. Apabila produk yang diproduksi oleh perusahaan tidak sesuai dengan standar yang telah ditetapkan, maka produk tersebut masuk ke dalam kelompok produk cacat. Produk cacat tersebut nantinya akan dianalisis penyebab kecacatannya oleh perusahaan, dan nantinya hasil analisis tersebut akan digunakan sebagai pegangan sekaligus pembelajaran agar nantinya perusahaan tidak melakukan kesalahan yang sama dan sebisa mungkin menghindari kesalahan tersebut agar proses produksi berjalan dengan lebih baik dan tentunya lebih berkualitas. Meminimumkan cacat adalah usaha yang harus 
I Gusti Ayu Andika Harum Sari dan Gede Mertha Sudiartha, Pengendalian Kualitas Pro...

dilakukan secara berkesinambungan dalam hal peningkatan kualitas suatu produk (Rachman, 2017).

Salah satu metode yang dapat membantu perusahaan untuk mengendalikan kualitas proses produksinya adalah menggunakan Statistical Quality Control (SQC). Metode statistik sangat diperlukan untuk memahami variabilitas dalam variabel produk dan proses selain itu penggunaan metode statistic juga dapat meminimalkan variabilitas yang berpengaruh langsung terhadap kualitas produk (Alkubaisi, 2013). Statistical Quality Control (SQC) merupakan teknik yang dikembangkan berdasarkan konsepsi mengenai variabilitas proses, yang secara luas diterapkan tidak hanya dalam proses manufaktur tetapi juga dalam operasi layanan jasa (Halim, 2014). SQC adalah alat yang efektif untuk pengendalian kualitas di semua jenis industri baik itu industri manufaktur ataupun di industri lainnya (Harpreet, 2016). SQC merupakan suatu sistem yang dikembangkan untuk menjaga standar dari kualitas hasil produksi, pada tingkat biaya yang minimum dengan menggunakan metode statistik untuk mengumpulkan dan menganalisis data (Rusdianto, 2011) . SQC merupakan suatu metode yang digunakan untuk memantau secara dinamis bagaimana kualitas produk yang sedang diproduksi oleh perusahaan (Omar, 2010). Pengendalian kualitas secara statistik (Statistical Quality Control) dapat digunakan untuk menemukan kesalahan produksi yang mengakibatkan produk cacat (Bakhtiar, 2013). Apabila perusahaan mampu menerapkan metode SQC ini dengan benar, maka perusahaan akan mampu mencegah masalah, mengontrol proses produksi mereka, dan pada akhirnya meningkatkan keuntungan dan kepuasan pelanggan (Madanhire, 2016). Penerapan 
metode SQC yang baik dan benar di dalam perusahaan dapat meningkatkan kinerja proses produksi serta mengurangi variabilitas produk dan meningkatkan efisiensi produksi dengan mengurangi pemborosan dan pengerjaan ulang (Mengesha, 2013)

Penelitian mengenai penggunaan Statistical Quality Control guna mengetahui proses produksi di perusahaan telah berjalan dengan baik atau belum sudah seringkali dilakukan. Penelitian yang dilakukan Ningsih dkk. (2016 Indriastuti (2017), Mostafaeipour dkk. (2012), Rizal (2017), Rachman (2017), Rusdianto (2011), Banker dkk. (2014), Bhosale (2013), Patidar (2015) dan Widiaswanti (2016) menyatakan bahwa pelaksanaan pengawasan kualitas pada perusahaan yang diteliti belum terlaksana dengan baik. Sedangkan penelitian Rahmadinanta dkk. (2015), Busyairi (2017), Ogedengbe dkk. (2016), Kemit dkk. (2016), Godina dkk. (2016), Elmas (2017), dan Suryaningrat dkk. (2015) menyatakan bahwa pengawasan kualitas pada perusahaan yang diteliti sudah dijalankan dengan baik, hal ini dapat dilihat dari tingkat kecacatan produk perusahaan yang masih berada dalam batas kendali.

Untuk menjaga kualitas suatu poduk perusahaan harus mengeluarkan biaya lebih, yang disebut dengan biaya kualitas. Biaya kualitas menurut Hansen dan Mowen (2009:272) adalah biaya-biaya yang timbul karena mungkin atau telah terdapat produk yang kualitasnya buruk. UD. Cipta Lestari adalah salah satu usaha dagang kopi yang memproduksi berbagai macam kopi, mulai dari kopi arabika, kopi luwak, kopi robusta, kopi olah basah, dan juga memproduksi kopi ekstrak dengan berbagai varian rasa. Kopi-kopi asal Desa Pujungan yang diproduksi di 
I Gusti Ayu Andika Harum Sari dan Gede Mertha Sudiartha, Pengendalian Kualitas Pro...

UD Cipta Lestari ini, telah tersebar luas di sejumlah kota besar di Indonesia dan telah mampu menembus pasar ekspor seperti Hongkong, Korea, Cina dan Belgia.

Kopi arabika merupakan salah satu jenis kopi yang sangat diminati karena memiliki cita rasa yang khas. Untuk kopi jenis arabika, UD. Cipta Lestari telah mampu memasarkan produk ini hingga sampai ke pasar Eropa. Sejak tahun 2012 UD. Cipta Lestari telah menjalin kerjasama dengan seorang pengusaha asal Belgia dan memberikan nama Café De Bali sebagai identitas merk produk kopi arabika yang di produksi oleh UD. Cipta Lestari dan diekspor ke Negara Belgia tersebut. Produk Kopi Arabika yang diekspor ke Belgia adalah dalam bentuk biji kopi yang telah di roosted dan sudah siap dikonsumsi. Proses produksi kopi arabika ini diawali dengan pemilihan biji kopi berkualitas, pengupasan kulit buah, fermentasi, pencucian, penjemuran, penyangraian, sortasi dan yang terakhir adalah pengemasan produk. Dalam setiap proses produksi tersebut terdapat beberapa faktor pengganggu yang dapat menyebabkan terjadinya kecacatan pada produk. Faktor penggangu tersebut antara lain adalah bahan baku, tenaga kerja, mesin dan cuaca.

Meskipun perusahaan telah berupaya untuk mengendalikan kualitas produk, namun beberapa permasalahan dalam proses produksi masih belum bisa diatasi secara maksimal, misalkan terdapat beberapa produk yang cacat atau tidak sesuai standar kualitas perusahaan. Apabila produk cacat tersebut tidak ditangani dengan baik maka kedepannya hal ini akan berakibat buruk bagi perusahaan. Oleh karena itu, diperlukan adanya upaya pengendalian kualitas secara lebih terperinci pada setiap proses produksi kopi arabika pada UD. Cipta Lestari. Adapun tujuan dari 
diadakannya penelitian ini adalah untuk mengetahui apakah pengendalian kualitas proses produksi yang dilakukan pada UD. Cipta lestari apakah sudah optimal atau belum. Hasil penelitian ini diharapkan dapat menjadi informasi serta dapat menjadib bahan pertimbangan pengambilan keputusan perusahaan sekaligus memberikan solusi guna memecahkan masalah yang dihadapi oleh perusahaan.

\section{METODE PENELITIAN}

Penelitian ini merupakan salah satu bentuk penelitian deskriptif dengan pendekatan kuantitatif. Menurut (Sukardi, 2008:54) penelitian deskriptif adalah metode penelitian yang berusaha menguraikan dan menginterpretasikan objek sesuai keadaan yang sebenarnya. Penelitian ini dilakukan pada salah satu perusahaan yang memproduksi kopi arabika yaitu UD. Cipta Lestari yang berada di Desa Pujungan, Kecamatan Pupuan, Tabanan, Bali.

Objek dalam penelitian ini adalah pengendalian kualitas proses produksi produk kopi arabika Café De Bali varian Black Double Roasting kemasan $1 \mathrm{~kg}$ yang diproduksi oleh UD. Cipta Lestari . Terdapat empat variabel yang menjadi titik perhatian dalam penelitian ini. Variabel tersebut antara lain, standar kualitas produk, jumlah produksi, jumlah produk cacat dalam proses produksi dan biaya kualitas.

Data yang digunakan dalam penelitian ini terdiri dari 2 data, yaitu data kualitatif yang berupa informasi antara lain mengenai gambaran umum perusahaan, jenis produk cacat, proses produksi, alat dan bahan baku yang digunakan dalam kegiatan produki serta pelaksanaan pengendalian kualitas dan juga Data mengenai jumlah produksi, jumlah produk cacat dalam setiap proses 
I Gusti Ayu Andika Harum Sari dan Gede Mertha Sudiartha, Pengendalian Kualitas Pro...

poduksi, harga jual, dan harga perawatan peralatan. Sumber data yang digunakana berasal dari dua sumber yaitu melalui sumber primer dan sumber sekunder.

Populasi dalam penelitian ini adalah hasil produksi kopi arabika selama 25 hari kerja yaitu sejumlah 1.875 bungkus, terhitung dari tanggal 27 Agustus 2018 sampai dengan 28 September 2018. Sampel yang digunakan dalam penelitian terdiri dari 50 bungkus kopi yang diambil setiap harinya dengan menggunakan metode random sampling atau selama 25 hari kerja terdapat 1.250 bungkus kopi yang akan diperiksa.

Proses analisis data dilakukan dengan menggunakan teknik pengendalian kualitas secara statistik dengan langkah-langkah sebagai berikut: Mengumpulkan data jumlah produksi dan jumlah produk cacat menggunakan Check Sheet, (2) Membuat Peta Kendali, (3) Mencari faktor penyebab kecacatan produk dengan menggunakan fishbone diagram, (4) Menghitung besaran biaya kualitas dan (5) Membuat rekomendasi/usulan perbaikan kualitas

\section{HASIL DAN PEMBAHASAN}

UD. Cipta Lestari merupakan perusahaan yang berlokasi di Desa Pujungan, Kecamatan Pupuan, Kabupaten Tabanan. Desa Pujungan merupakan salah satu desa yang terkenal sebagai desa penghasil kopi di Bali. Perusahaan ini secara resmi berdiri pada tahun 2008 dan bergerak dibidang perdagangan serta sebagai produsen berbagai varian kopi seperti kopi luwak, kopi arabika dan kopi robusta. Selain kopi, perusahaaan ini juga sebagai produsen gula aren, ekstrak jahe, kunyit, temulawak dan juga ekstrak rosela. Bahan baku yang digunakan untuk kegiatan 
produksi perusahaan sebagian besar berasal dari petani sekitar di area Kecamatan Pupuan.

Pada awal berdirinya, perusahaan ini hanya bergerak dibidang perdagangan, dimana perusahaan hanya menjual apa yang dikumpulkannya dari petani sekitar, tapi kemudian melihat potensi kopi yang semakin membaik maka Bapak I Wayan Dira selaku pemilik usaha mulai memutuskan untuk mengolah biji kopi mentah menjadi produk yang lebih bernilai. Proses produksi kopi dilakukan setiap hari untuk memenuhi permintaan dari konsumen. Perusahaan mulai melaksanakan produksi pada pukul 08.00 WITA hingga pukul 17.00 WITA, saat ini perusahaan memperkerjakan sejumlah 10 pekerja guna melaksanakan segala kegiatan produksi yang harus dilakukan perusahaan.

UD. Cipta Lestari dengan ijin usaha nomor: 6105702 159, kini telah menjadi salah satu perusahaan yang terpandang, khususnya di Kabupaten Tabanan. Produk hasil produksi UD. Cipta Lestari telah tersebar luas disejumlah kota besar di Indonesia, seperti Jakarta, Bandung, Surabaya, Semarang dan Medan. Tidak hanya beredar di Indonesia, produk kopi olahan UD. Cipta Lestari sejak tahun 2016 telah mampu menembus pasar luar negeri seperti Belgia, Jepang, Hongkong dan China. Kesuksesan perusahaan dalam memasarkan produknya ini membuat perusahaan menjadi panutan dan motivasi bagi UMKM sejenis lainnya untuk dapat meraih kesuksesannya sendiri. Kesuksesan yang diperoleh perusahaan tidak terlepas dari usaha dan kerja keras Bapak I Wayan Dira selaku pemilik usaha yang tidak pernah menyerah dan selalu ingin belajar untuk menjadi lebih baik. 
I Gusti Ayu Andika Harum Sari dan Gede Mertha Sudiartha, Pengendalian Kualitas Pro...

Secara umum tahapan produksi kopi arabika bersifat homogen atau sama. Pada proses produksi perusahaan UD. Cipta Lestari yang menjadi standar perusahaan terdiri dari beberapa tahap, yaitu sebagai berikut: (1) Proses Sortasi Buah Kopi, (2) Pengupasan Kulit Buah (Pulping), (3) Fermentasi, (4) Pencucian (Washing), (5) Pengeringan, (6) Pengupasan Kulit Kopi HS (Hulling), (7) Sortasi Biji Kopi Beras, (8) Penyangraian Biji Kopi Arabika Beras, (9) Sortasi Biji Kopi Arabika Beras Roasted, (10) Pengemasan.

Kopi arabika yang diproduksi oleh UD. Cipta Lestari dikemas dengan berbagai ukuran yang berbeda tergantung dengan keinginan konsumen. Untuk produk kopi arabika Café De Bali varian Black Double Roasting kemasan $1 \mathrm{~kg}$ perusahaan telah menetapkan standar kualitas sebagai berikut.

\section{Tabel 1.}

Standar Kualitas Produk Kopi Arabika di UD. Cipta Lestari

\begin{tabular}{|c|c|c|}
\hline No & Kategori & Standar \\
\hline 1 & Warna & Biji kopi arabika berwarna coklat terang. \\
\hline 2 & Bentuk & Biji kopi arabika memiliki bentuk utuh dan tidak cacat \\
\hline 3 & Gramasi & $\begin{array}{l}\text { Berat produk jadi sesuai dengan apa yang tertera dalam kemasan. Dalam hal ini, } \\
\text { berat bersih yang ditetapkan untuk produk kopi arabika Café De Bali varian } \\
\text { Black Double Roasting oleh perusahaan adalah } 1.000 \text { gram, sedangkan berat } \\
\text { kotornya adalah } 1.025 \text { gram. }\end{array}$ \\
\hline 4 & Kemasan & $\begin{array}{l}\text { Produk dikemas dengan rapi, dengan kemasan yang bersih dan telah ditempelkan } \\
\text { stiker logo yang tercetak dengan baik dan terpasang dengan lurus. }\end{array}$ \\
\hline
\end{tabular}

Berdasarkan hasil pengumpulan data yang dilakukan di Perusahaan, maka dapat diperoleh data berupa jumlah produksi serta jumlah kecacatan produk yang terjadi selama 25 hari kerja, adalah sebagai berikut:

Berdasarkan data pada Tabel 2, dapat diketahui bahwa dari total sampel sebesar 1250 bungkus kopi arabika yang diperiksa dalam 25 hari kerja terdapat 37 bungkus kopi arabika Café De Bali varian Black Double Roasting yang mengalami kecacatan. Terdapat empat kategori kecacatan yang terjadi pada 
produk, yaitu karena kemasan yang kurang sesuai, gramasi yang tidak sesuai, warna yang tidak sesuai dan juga bentuk biji kopi arabika yang sudah tidak utuh lagi.

Tabel 2.

Jenis dan Jumlah Kecacatan Produk Kopi Arabika

\begin{tabular}{|c|c|c|c|c|c|c|}
\hline \multirow[b]{2}{*}{ Hari Ke- } & \multirow[b]{2}{*}{ Sampel } & \multicolumn{4}{|c|}{ Jenis Kecacatan } & \multirow[b]{2}{*}{$\begin{array}{c}\text { Jumlah } \\
\text { Cacat }\end{array}$} \\
\hline & & $\begin{array}{c}\text { Kemasan } \\
\text { Cacat }\end{array}$ & $\begin{array}{c}\text { Gramasi } \\
\text { Tidak Sesuai }\end{array}$ & $\begin{array}{c}\text { Warna } \\
\text { Coklat Tua }\end{array}$ & $\begin{array}{c}\text { Bentuk } \\
\text { Tidak Utuh }\end{array}$ & \\
\hline 1 & 50 & 1 & & & & 1 \\
\hline 2 & 50 & & & & & 0 \\
\hline 3 & 50 & & 1 & & 3 & 4 \\
\hline 4 & 50 & & & & & 0 \\
\hline 5 & 50 & & & & & 0 \\
\hline 6 & 50 & 1 & 1 & 2 & & 4 \\
\hline 7 & 50 & & & & 2 & 2 \\
\hline 8 & 50 & & & & & 0 \\
\hline 9 & 50 & 1 & 1 & 1 & & 3 \\
\hline 10 & 50 & & & & & 0 \\
\hline 11 & 50 & & & & 3 & 3 \\
\hline 12 & 50 & & & 2 & & 2 \\
\hline 13 & 50 & & 2 & & 1 & 3 \\
\hline 14 & 50 & & & 1 & & 1 \\
\hline 15 & 50 & & & & & 0 \\
\hline 16 & 50 & 2 & & & 2 & 4 \\
\hline 17 & 50 & & 1 & & 1 & 2 \\
\hline 18 & 50 & & & & & 0 \\
\hline 19 & 50 & 1 & 1 & & & 2 \\
\hline 20 & 50 & & & & & 0 \\
\hline 21 & 50 & & & & 1 & 1 \\
\hline 22 & 50 & 1 & & & & 1 \\
\hline 23 & 50 & & 1 & 1 & & 2 \\
\hline 24 & 50 & 1 & & & & 1 \\
\hline
\end{tabular}


I Gusti Ayu Andika Harum Sari dan Gede Mertha Sudiartha, Pengendalian Kualitas Pro...

\begin{tabular}{ccccccc}
$\mathbf{2 5}$ & 50 & & 1 & & 1 \\
Total & $\mathbf{1 2 5 0}$ & $\mathbf{8}$ & $\mathbf{9}$ & $\mathbf{7}$ & $\mathbf{1 3}$ & $\mathbf{3 7}$ \\
Rata-Rata & $\mathbf{5 0}$ & $\mathbf{0 . 3 2}$ & $\mathbf{0 . 3 6}$ & $\mathbf{0 . 2 8}$ & $\mathbf{0 . 5 2}$ & $\mathbf{1 . 4 8}$ \\
\hline Sumber: Data & Observasi 2018
\end{tabular}

Berdasarkan keempat kategori yang ada, terlihat bahwa kecacatan produk tertinggi diakibatkan oleh bentuk biji kopi yang sudah tidak utuh lagi. Dari 1250 bungkus produk yang diinsfeksi, terdapat 8 bungkus produk yang dikategorikan ke dalam produk cacat akibat kemasannya yang kurang rapi atau kotor. Selain itu 9 bungkus produk dikategorikan cacat akibat gramasinya tidak sesuai dengan keterangan di kemasan produk, selanjutnya 7 bungkus produk dikategorikan cacat karena dalam $1 \mathrm{~kg}$ bji kopi terdapat lebih dari 20 gram biji kopi yang memiliki warna coklat tua yang dimana artinya biji kopi tersebut terlalu matang dan memiliki cita rasa pahit yang akan mengganggu cita rasa biji kopi lainnya. Terakhir, sejumlah 13 bungkus biji kopi arabika dikategorikan produk cacat akibat ditemukan 20 gram biji kopi yang tidak utuh dalam kemasan $1 \mathrm{~kg}$ kopi arabika Café De Bali varian Black Double Roasting.

Dalam Membuat peta kendali P, maka perlu diketahui terlebih dahulu persentase kecacatan produk yang terjadi di perusahaan. Berdasarkan hasil perhitungan menggunakan Microsoft Excel, maka diketahui persentase kecacatan produk pada UD. Cipta Lestari selama 25 hari kerja adalah sebagai berikut:

Tabel 3.

Persentase Kecacatan Produk

\begin{tabular}{ccccc}
\hline Hari Ke- & Sampel & $\begin{array}{c}\text { Produk } \\
\text { Cacat }\end{array}$ & $\begin{array}{c}\text { Proporsi } \\
\text { Kecacatan }\end{array}$ & $\begin{array}{c}\text { Persentase } \\
\text { Kecacatan }\end{array}$ \\
\hline $\mathbf{1}$ & 50 & 1 & 0.02 & $2 \%$ \\
$\mathbf{2}$ & 50 & 0 & 0 & $0 \%$ \\
$\mathbf{3}$ & 50 & 4 & 0.08 & $8 \%$
\end{tabular}




\begin{tabular}{|c|c|c|c|c|}
\hline 4 & 50 & 0 & 0 & $0 \%$ \\
\hline 5 & 50 & 0 & 0 & $0 \%$ \\
\hline 6 & 50 & 4 & 0.08 & $8 \%$ \\
\hline 7 & 50 & 2 & 0.04 & $4 \%$ \\
\hline 8 & 50 & 0 & 0 & $0 \%$ \\
\hline 9 & 50 & 3 & 0.06 & $6 \%$ \\
\hline 10 & 50 & 0 & 0 & $0 \%$ \\
\hline 11 & 50 & 3 & 0.06 & $6 \%$ \\
\hline 12 & 50 & 2 & 0.04 & $4 \%$ \\
\hline 13 & 50 & 3 & 0.06 & $6 \%$ \\
\hline 14 & 50 & 1 & 0.02 & $2 \%$ \\
\hline \multicolumn{5}{|c|}{$\begin{array}{l}\text { Bersambung.... } \\
\text { Lanjutan Tabe }\end{array}$} \\
\hline Hari Ke- & Sampel & $\begin{array}{c}\text { Produk } \\
\text { Cacat }\end{array}$ & $\begin{array}{c}\text { Proporsi } \\
\text { Kecacatan }\end{array}$ & $\begin{array}{l}\text { Persentase } \\
\text { Kecacatan }\end{array}$ \\
\hline 15 & 50 & 0 & 0 & $0 \%$ \\
\hline 16 & 50 & 4 & 0.08 & $8 \%$ \\
\hline 17 & 50 & 2 & 0.04 & $4 \%$ \\
\hline 18 & 50 & 0 & 0 & $0 \%$ \\
\hline 19 & 50 & 2 & 0.04 & $4 \%$ \\
\hline 20 & 50 & 0 & 0 & $0 \%$ \\
\hline 21 & 50 & 1 & 0.02 & $2 \%$ \\
\hline 22 & 50 & 1 & 0.02 & $2 \%$ \\
\hline 23 & 50 & 2 & 0.04 & $4 \%$ \\
\hline 24 & 50 & 1 & 0.02 & $2 \%$ \\
\hline 25 & 50 & 1 & 0.02 & $2 \%$ \\
\hline Total & 1250 & 37 & 0.74 & $74 \%$ \\
\hline Rata-Rata & $\mathbf{5 0}$ & 1.48 & 0.0296 & $3.0 \%$ \\
\hline
\end{tabular}

Sumber: Data Observasi 2018

Berdasarkan data pada Tabel 3, dapat diketahui bahwa dari 1250 bungkus biji kopi arabika Café De Bali varian Black Double Roasting yang diperiksa selama bulan Agustus-September 2018 Terbapat 37 bungkus produk yang mengalami kecacatan, sehingga proporsi kerusakan produk rata-rata pada UD. Cipta Lestari adalah sebesar 0,0296 atau 3\%.

Tabel 5. 
I Gusti Ayu Andika Harum Sari dan Gede Mertha Sudiartha, Pengendalian Kualitas Pro...

\section{Batas-batas Kendali Kecacatan Biji Kopi Arabika Café De Bali varian Black} Double Roasting pada Bulan Agustus s.d September Tahun 2018

\section{Uraian}

Jumlah Sampel Produksi (Bungkus)

Jumlah Kerusakan Produk (Bungkus)

CL

UCL

LC

Sumber: Data diolah, 2018
Jumlah

1250

37

$\mathbf{0 . 0 3 0}$

0.102

$-0.042$

Agar lebih jelasnya dapat dilihat dengan rincian perhitungan untuk mendapatkan Central Line (Cl), Upper Control Limit (UCL) dan Lower Control Limit (LCL) adalah sebagai berikut.

1) Menghitung Central Line (CL)

$\mathrm{CL}=\frac{37}{1250}$

$$
=0.030
$$

2) Menghitung Upper Control Limit (UCL)

$$
\begin{aligned}
\mathrm{UCL}= & 0.030+3\left(\sqrt{\frac{0.030(1-0.030)}{50}}\right) \\
& =0.030+3(0.024) \\
& =0.030+0.072
\end{aligned}
$$

$$
=0.102
$$

3) Menghitung Lower Control Limit (LCL)

$$
\begin{aligned}
\mathrm{LCL} & =0.030-3\left(\sqrt{\left.\frac{0.030(1-0.030)}{50}\right)}\right. \\
& =0.030-3(0.024) \\
& =0.030-0.072
\end{aligned}
$$




$$
=-0.042
$$

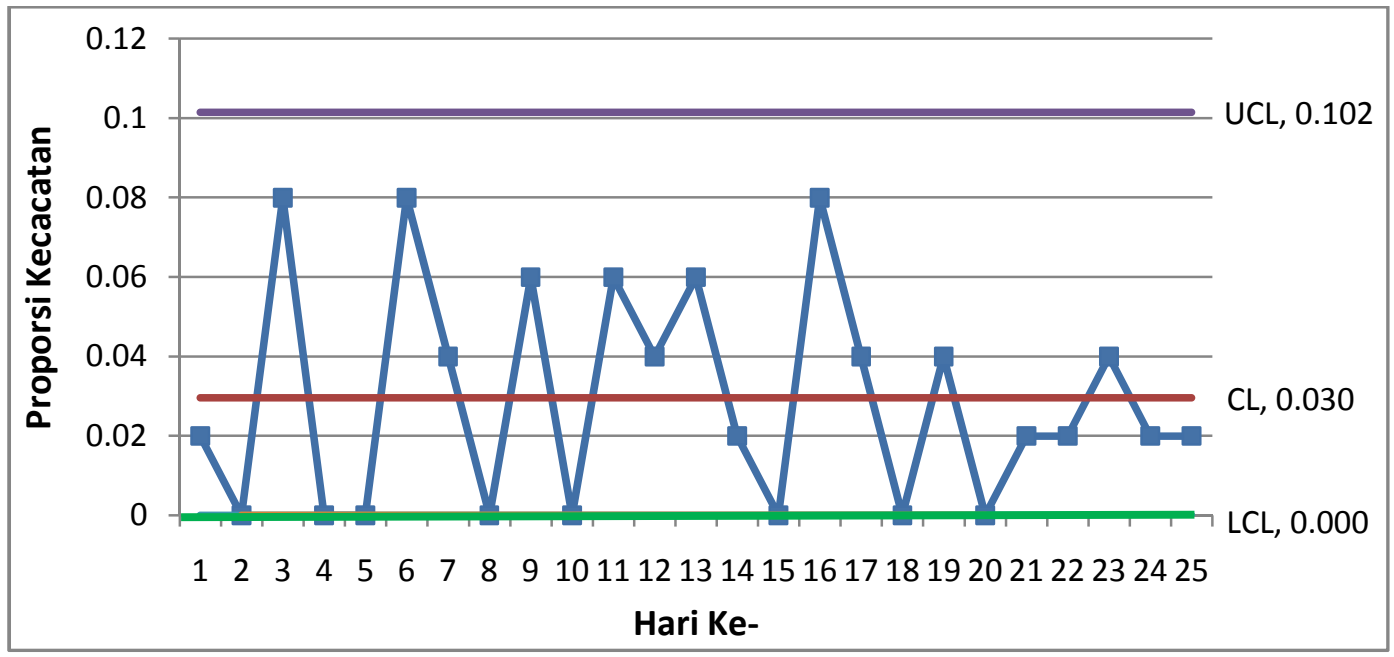

\section{Gambar 1. P-chart Kerusakan Produk Biji Kopi Arabika}

Sumber: Data diolah, 2018

Berdasarkan Gambar 1 dapat dilihat bahwa seluruh titik proporsi kecacatan sejumlah 25 titik berada diantara batas kendali (UCL dan LCL), hal ini berarti bahwa pengendalian kualitas proses produksi biji kopi arabika sudah berjalan dengan baik.

Kecacatan produk di perusahaan UD. Cipta Lestari berdasarkan hasil wawancara serta observasi langsung di lapangan disebabkan oleh faktor tenaga kerja, mesin, metode serta lingkungan kerja di perusahaan. Berdasarkan data hasil analisis jumlah produk cacat yang terdapat pada Tabel 2 dapat diketahui bahwa jumlah total produk cacat adalah sejumlah 37 bungkus biji kopi dengan jenis kerusakan/kecacatan yang terdiri dari kemaran kurang rapi atau kurang bersih sejumlah 8 bungkus, gramasi yang tidak sesuai sejumlah 9 bungkus, warna biji kopi yang tidak sesuai standar sejumlah 7 bungkus, dan bentuk biji kopi yang 
I Gusti Ayu Andika Harum Sari dan Gede Mertha Sudiartha, Pengendalian Kualitas Pro...

tidak utuh sejumlah 13 bungkus. Keempat jenis kerusakan tersebut akan dianalisis faktor penyebabnya menggunakan diagram sebab-akibat.

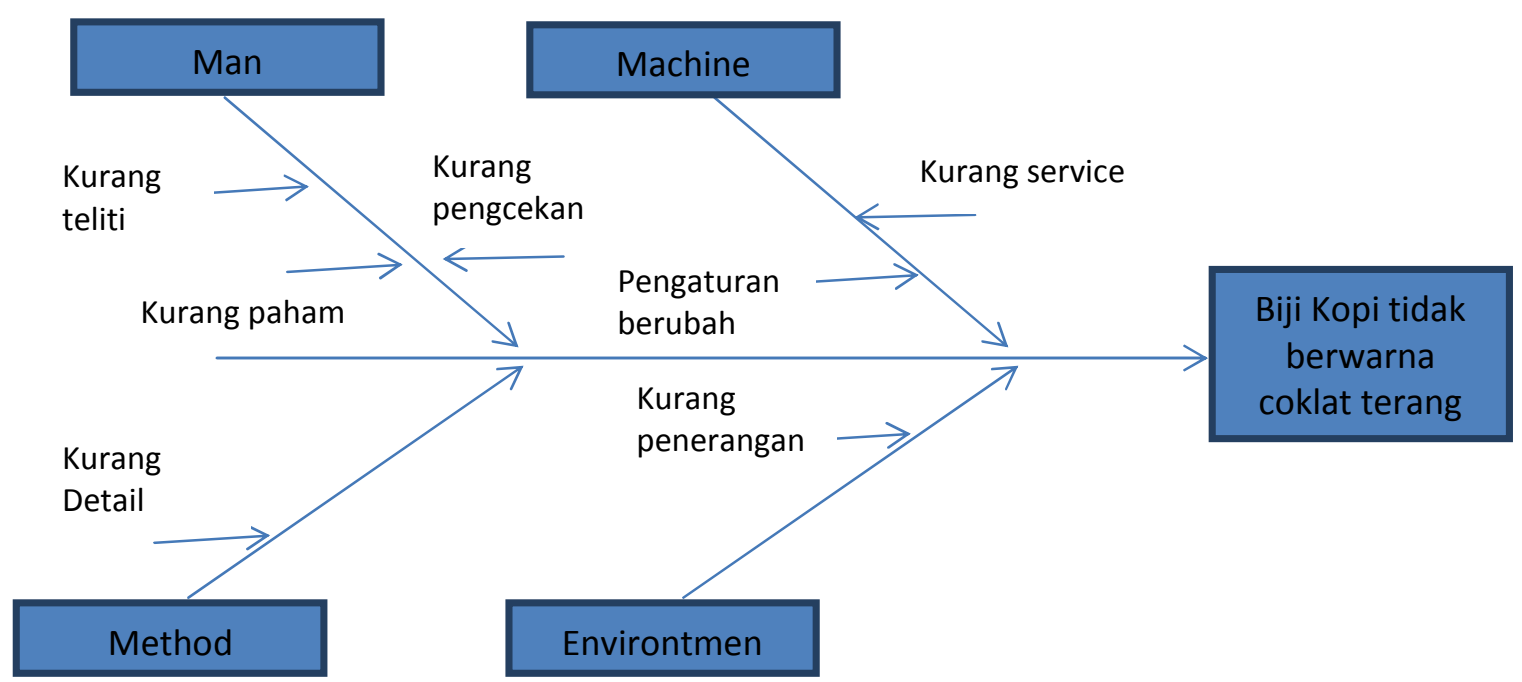

\section{Gambar 2. Fishbone Diagram Produk Cacat Biji Kopi Tidak Berwarna Coklat Terang \\ Sumber: Data diolah, 2018}

Berdasarkan Gambar 2 dapat diketahui bahwa kecacatan pada biji kopi yang tidak berwarna coklat terang disebabkan oleh beberapa faktor, yaitu faktor manusia, metode, mesin dan lingkungan. Faktor pertama adalah faktor manusia/tenaga kerja, dimana tenaga kerja yang bertugas ntuk mengendalikan mesin kurang memahami proses yang harusnya dilakukan, selain itu tenaga kerja seringkali kurang teliti saat melakukan proses sortasi terakhir hal ini menyebabkan beberapa biji kopi yang tidak sesuai standar masuk kedalam kemasan.

Faktor kedua adalah mesin pengoven/sangrai, pada beberapa kejadian mesin mengalami error saat melakukan kegiatannya, hal ini menyebabkan beberapa biji kopi memiliki tingkat kematangan yang lebih tinggi dibandingkan dengan yang lainnya. Faktor ketiga adalah disebabkan oleh metode, dimana tidak semua tenaga kerja memahami metode/instruksi yang ditentukan oleh perusahaan, kurangnya 
pemahaman akan metode ini seringkali disebabkan karena kurang detailnya metode yang disosialisasikan di perusahaan. Faktor terakhir adalah faktor lingkungan, dimana lingkungan kerja yang kurang nyaman akan menyebabkan tenaga kerja kurang konsentrasi saat melaksanakan tugasnya, misalkan saja saat melakukan sortasi manual, tenaga kerja tentunya membutuhkan tempat kerja yang nyaman dan memiliki penerangan cukup agar dapat lebih berkonsentrasi dalam memilah biji kopi.

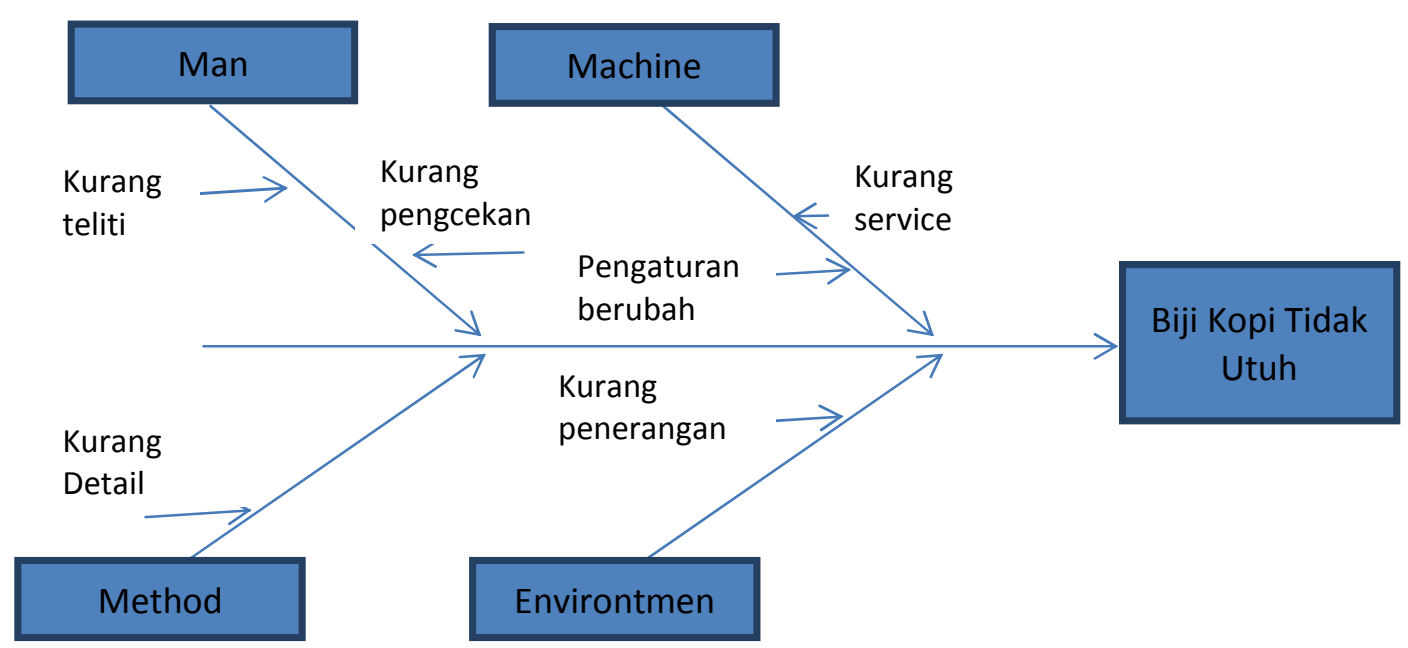

\section{Gambar 3. Fishbone Diagram Produk Cacat Biji Kopi Tidak Utuh}

Sumber: Data diolah, 2018

Berdasarkan Gambar 3 dapat diketahui bahwa kecacatan pada biji kopi yang pecah disebabkan oleh beberapa faktor, yaitu faktor manusia, metode, mesin dan lingkungan. Faktor pertama adalah faktor manusia/tenaga kerja, ditemukannya biji kopi yang pecah dalam kemasan disebabkan karena kurang telitinya pekerja saat melakukan sortasi manual, meskipun biji kopi pecah nantinya tidak akan mempengaruhi cita-rasa dari kopi ini setelah diseduh, namun bentuk biji yang sudah tidak utuh ini dapat mengindikasikan perusahaan kurang menjaga kualitas dari produknya. 
I Gusti Ayu Andika Harum Sari dan Gede Mertha Sudiartha, Pengendalian Kualitas Pro...

Faktor kedua adalam faktor mesin, dimana pecahnya biji kopi ini biasanya terjadi pada tahap Hulling (pengupasan kulit kopi), mein huller yang kurang diperhatikan/diservice dapat menyebabkan mesin kurang terkendali dan berpengaruh terhadap bentuk biji kopi. Faktor selanjutnya adalah metode, beberapa tenaga kerja kurang memahami bagaimana cara kerja mesin huller yang digunakannya, hal ini menyebabkan mesin bekerja tidak sesuai standar perusahaan. Faktor terakhir adalah faktor lingkungan, sama seperti sebelumnya tenaga kerja yang betugas menyortasi biji kopi yng telah disangrai akan mengalami kesulitan untuk berkonsentrasi dilingkungan yang bising dan tentunya proses sortasi manual ini membutuhkan tempat yang memiliki pencahayaan yang cukup.

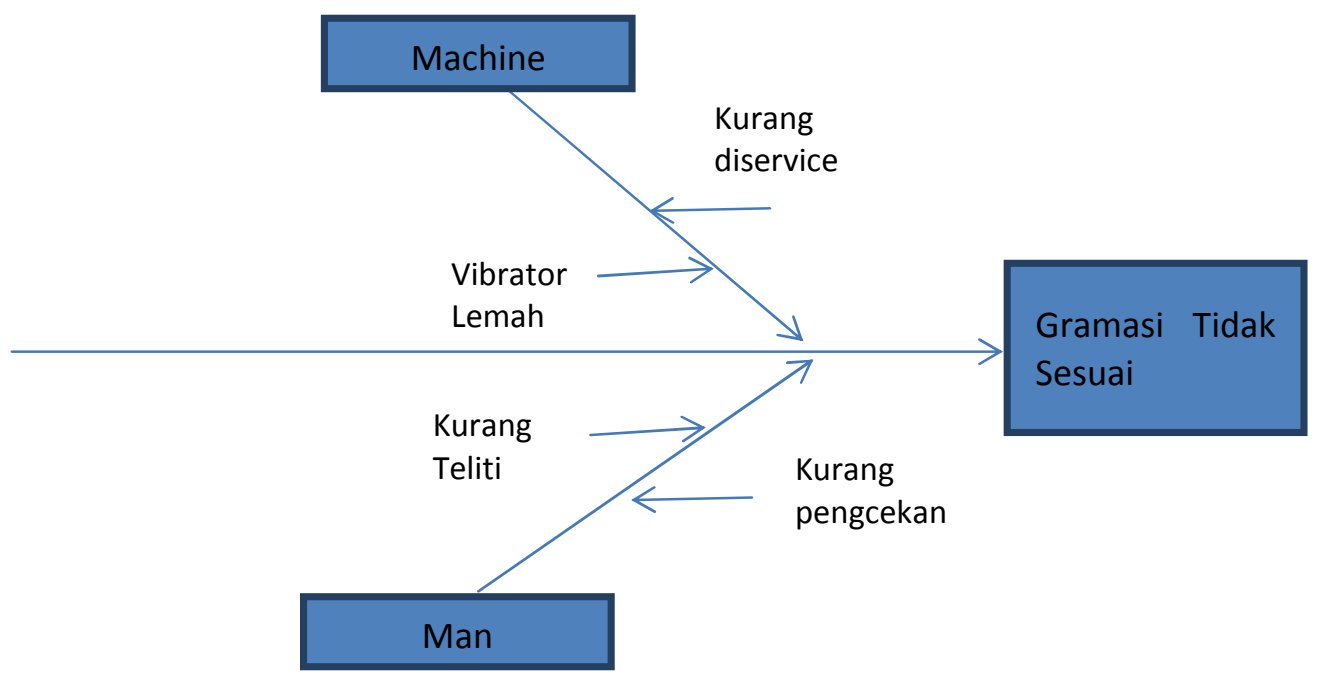

\section{Gambar 4. Fishbone Diagram Produk Cacat Gramasi Tidak Sesuai}

Sumber: Data diolah, 2018

Berdasarkan Gambar 4 dapat diketahui bahwa kecacatan pada gramasi produk disebabkan oleh 2 faktor, yaitu faktor manusia,dan faktor mesin. Faktor pertama adalah faktor mesin, dalam proses penimbangan produk sebelum dilakukan pengemasan perusahaan menggunakan timbangan digital kecil dalam 
kegiatannya ini. Banyaknya produk yang harus ditimbang satu-persatu ini seringkali menyebabkan timbangan error akibat bekerja terlalu keras, hal ini menunjukkan bahwa mesin timbangan kurang di service, selain itu beberapa timbangan juga memiliki vibrator yang rendah sehingga keakuratannya diragukan.

Selain faktor mesin, faktor manusia yang melakukan proses pengukuran ini juga memegang peranan yang penting, seringkali tenaga kerja kurang teliti saat melakukan penimbangan dan mengabaikan angka yang tertera karena dirasa penyimpangannya masih rendah, padahal apabila hal itu dibiarkan terus menerus tentunya akan menyebabkan permasalahan kedepannya bagi perusahaan karena berat yang terera dalam kemasan tidak sesuai dengan berat sesungguhnya.

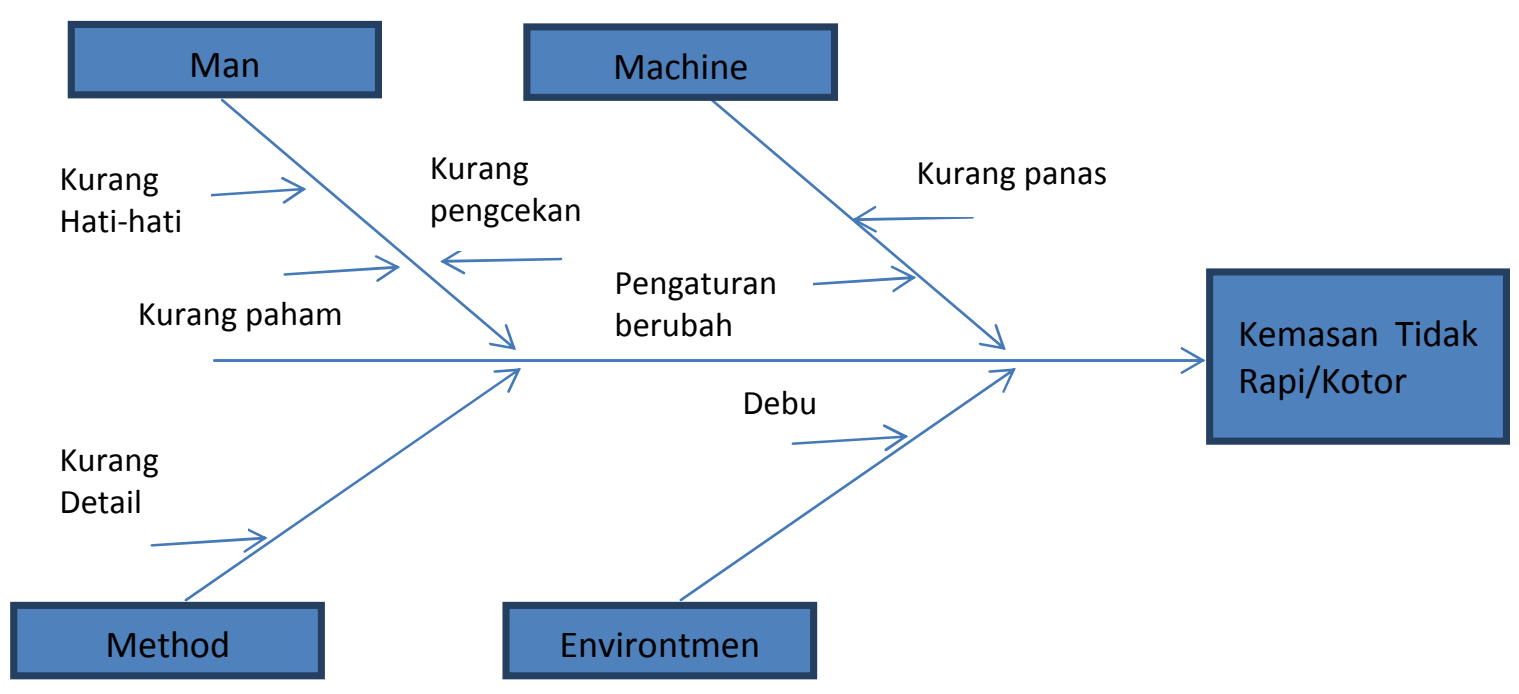

Gambar 4. Fishbone Diagram Produk Cacat Kemasan Tidak Rapi/Kotor Sumber: Data diolah, 2018

Berdasarkan Gambar 5 dapat diketahui bahwa kecacatan pada kemasan produk disebabkan oleh beberapa faktor, yaitu faktor manusia, metode, mesin dan lingkungan. Faktor pertama adalah faktor manusia/tenaga kerja, karena proses 
I Gusti Ayu Andika Harum Sari dan Gede Mertha Sudiartha, Pengendalian Kualitas Pro...

pengemasan yang dilakukan di perusahaan masih dilakukan secara manual, jadi manusia merupakan faktor utama yang menyebabkan kemasan produk menjadi tidak sesuai dengan standar. Beberapa tenaga kerja sering kali kurang berhatihati saat melalukan pegemasan sehingga menyebabkan kemasan kurang rapi, selain itu juga seringkali tenaga kerja kurang memahami bagaimana cara kerja mesin sealer yang benar, sehingga menyebabkan kemasan kurang rapi.

Faktor selanjutnya adalah faktor mesin, dimana seringkali mesin secara otomatis merubah aturan yang telah di setting sebelumnya, hal ini biasanya disebabkan karena mesin sudah bejkerja terlalu keras, sehingga menyebabkan error. Faktor metode juga merupakan salah satu faktor yang dapat mempengaruhi penyimpangan pada produk, apabila tenaga kerja tidak mengikuti instruki penggunaan mesin yang benar maka hal ini akan menyebabkan kemasan produk tidak rapi. Faktor terakhir adalah faktor lingkungan, dimana kondisi lingkungan yang kurang bersih dan berdebu akan mempengaruhi kemasan produk, seringkali debu-debu menempel pada kemasan dan apabila dibiarkan begitu saja maka debu itu akan menggumpal dan mengganggu kebersihan kemasan.

Berdasarkan peta kendali yang ditampilkan sebelumnya, dapat diketahui bahwa pengawasan kualitas di Perusahaan UD. Cipta Lestari sudah baik, namun untuk mengetahui apakah pengendalian kualias yang dilakukan tersebut sudah optimal atau belum, maka perlu dilakukan analisis mengenai biaya kualitas. Adapun biaya pengawasan kualitas yang harus dikeluarkan perusahaan terdiri dari biaya perawatan bahan baku sejumlah Rp. 400.000 setiap bulannya dan biaya pemeliharaan peralatan (mesin) sejumlah Rp. 850.000 setiap 3 bulannya. Selain 
itu perusahaan juga harus mengeluarkan biaya jaminan kualitassebesar seperempat dari harga jual rata-rata per bungkus produk (Rp. 120.000/4), yaitu Rp. 30.000

Tabel 6.

Perbandingan Biaya Aktual dengan Biaya Optimum Perusahaan

\begin{tabular}{lccc}
\hline \multicolumn{1}{c}{ Indikator } & Aktual & Optimum & \multicolumn{1}{c}{ Selisih } \\
\hline Jumlah Kerusakan (bungkus) & 148 & 111.80 & 36.20 \\
Biaya Pengawasan Kualitas (Rp) & $2,533,783.78$ & $3,354,203.94$ & $820,420.15$ \\
Biaya Jaminan Kualitas (Rp) & $4,440,000.00$ & $3,354,000.00$ & $1,086,000.00$ \\
Total Biaya Kualitas (Rp) & $\mathbf{6 , 9 7 3 , 7 8 3 . 7 8}$ & $\mathbf{6 , 7 0 8 , 2 0 3 . 9 4}$ & $\mathbf{2 6 5 , 5 7 9 . 8 5}$ \\
\hline
\end{tabular}

Sumber: Data diolah, 2018

Berdasarkan Tabel 5 diatas, dapat dilihat bahwa jumlah kerusakan aktual sebesar 148 bungkus kopi arabika lebih besar dibandingkan jumlah batas kerusakan biaya optimum yaitu sebesar 111,80 bungkus kopi arabika, namun untuk biaya pengawasan kualitasnya, biaya yang dikeluarkan untuk pengendalian kualitas optimum lebih rendah dibandingkan dengan biaya pengawasan kualitas optimum yang harus dikeluarkan perusahaan, dimana selisihnya sejumlah Rp. $820.420,15$. Sedangkan untuk biaya jaminan kualitas aktual yang harus dikeluarkan perusahaan terlihat lebih tinggi dibandingkan dengan biaja jaminan kualitas optimum, dimana selisih antara biaya jaminan kualitas aktual dan optimum adalah sejumlah Rp. 1.086.000. Selisih total biaya kualitas aktual dengan biaya kualitas optimum sejumlah Rp. 265.579,85 mengidentifikasikan bahwa pengendalian kualitas yang dilakukan UD. Cipta Lestari masih belum 
I Gusti Ayu Andika Harum Sari dan Gede Mertha Sudiartha, Pengendalian Kualitas Pro...

optimal.. Berikut merupakan grafik mengenai hubungan antara biaya total kualitas dan tingkat kecacatan produk kopi arabika yang dibebankan perusahan :

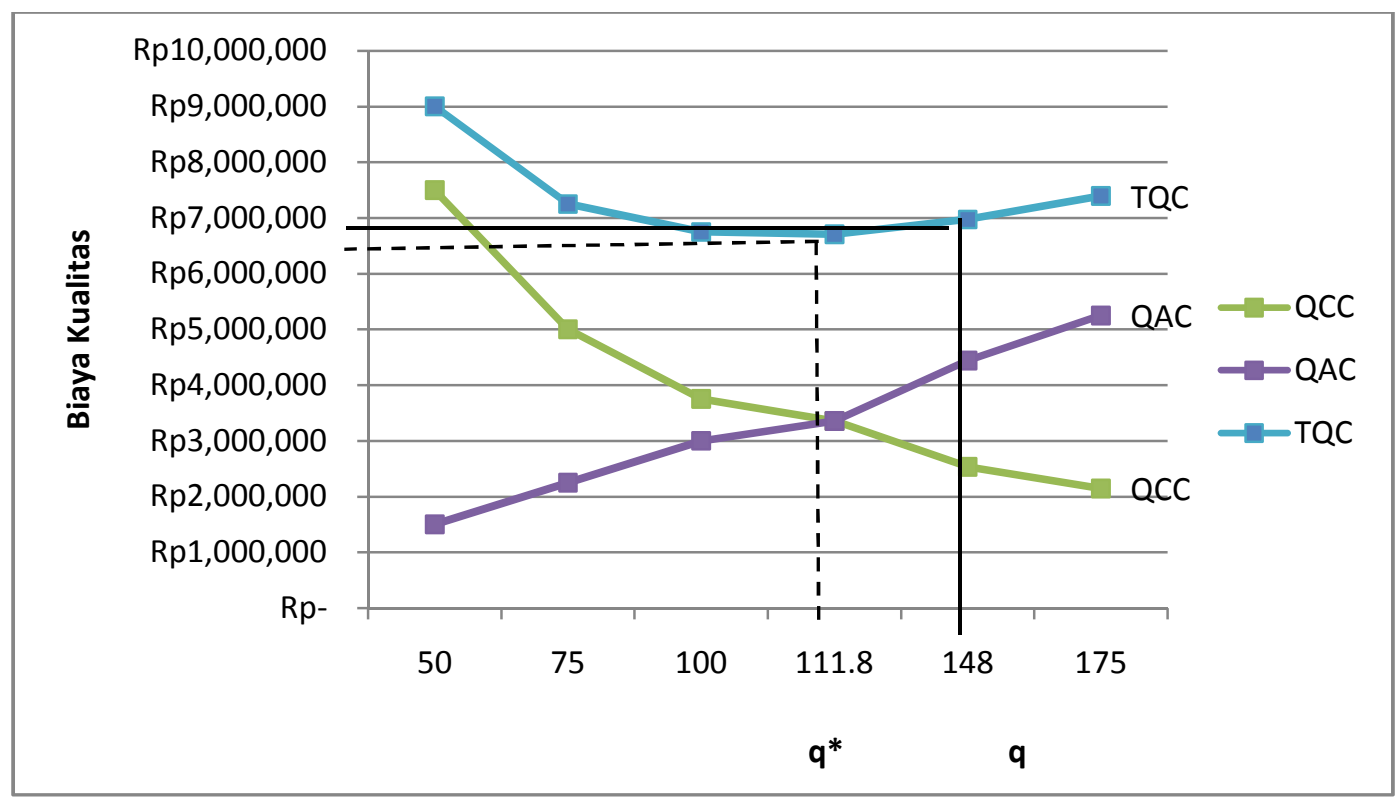

Gambar 5. Biaya Kualitas Produk Kopi Arabika UD. Cipta Lestari

Sumber: Data diolah, 2018

Gambar 6 diatas menunjukkan bahwa selama periode tahun 2018 jumlah kerusakan produk pada perusahaan UD. Cipta Lestari adalah sebesar 148 bungkus kopi arabika. Untuk dapat menmpertahankan kualitas perusahaan telah mengeluarkan biaya-biaya sebagai berikut, yaitu maka biaya pengawasan kualitas (QCC) sejumlah Rp. 2,533,783.78 dan biaya jaminan kualitas (QAC) sebesar Rp.4,440,000 sehingga total biaya kualitas (TQC) yang dikeluarkan perusahaan adalah sejumlah Rp. 6,973,783.78. Apabila dibandingkan dengan biaya kualitas optimum, dimana biaya pengawasan kualitas pada titik optimum $\left(\mathrm{QCC}^{*}\right)$ adalah sejumlah Rp.3,354,203.94, sedangkan biaya jaminan kualitas optimum (QAC*) sejumlah Rp.3,354,000.00 , sehingga total biaya kualitas opimum (TQC ${ }^{*}$ ) adalah 
sebesar Rp.6,708,203.94. Dari analisis biaya tersebut, dapat disimpulkan bahwa pengawasan kualitas yang dilakukan masih kurang optimal, hal ini terlihat dari besaran biaya kualitas aktual yang lebih tinggi dibandingkan biaya kualitas optimum perusahaan.

Langkah berikutnya setelah diketahuinya penyebab terjadinya kecacatan/penyimpangan pada produk biji kopi arabika pada UD. Cipta Lestari adalah menyusun suatu usahan tindakan perbaikan. Adapun upaya yang dapat dilakukan untuk mengurangu kecacatan produk adalah sebagai berikut : (1) Faktor Manusia, faktor manusia sebagai faktor utama yang sangat penting dalam proses produksi ini harus diberikan perhatian yang lebih. Pemilik usaha diharapkan dapat memilih tenaga kerja yang memang mau bersungguh-sungguh bekerja dan tidak malas. Hal ini karena proses produksi kopi arabika ini sangat banyak menggunakan tenaga kerja manusia, jadi apabila tenaga kerja yang dimiliki perusahaan malas, maka jumlah produkcacat akan otomatis meningkat, hal ini tentunya akan mempengaruhi reputasi dan pendapatan perusahaan. (2) Faktor Mesin, mesin sebagai alat yang membantu perusahaan untuk menjalankan seluruh aktifitasnya harus diberikan perlakuan yang baik, mulai dari dibersihkan dengan baik setiap sehabis produksi dan dilakukan perawatan yang rutin setiap bulannya. Investasi perusahaan pada perawatan mesin tentunya akan menimbulkan dampak yang baik kedepannya, hal ini karena permasalahan penyimpangan produk tidak dapat dipisahkan dari mesin-mesin yang kurang perawatan. (3) Faktor Metode, metode yang digunakan oleh perusahaan untuk melakukan kegiatan produksi tentunya harus disosialisasikan kepada seluruh karyawan agar tidak terjadi 
I Gusti Ayu Andika Harum Sari dan Gede Mertha Sudiartha, Pengendalian Kualitas Pro...

kesalahan penanganan produk/mesin yang menyebabkan produk tidak sesuai dengan standar yang ditetapkan perusahaaan. Sebaiknya perusahaan memasang poster mengerai instruksi penjalanan mesin atau instruksi lainnya di tempattempat yang dirasa tepat. Hal ini akan membuat tenaga kerja lebih memahami metode yang seharusnya diikuti dan menyebabkan penyimpangan pada produk dapat berkurang. (4) Faktor Lingungan, lingkungan kerja sangat mempengaruhi kinerja karyawan dan secara tidak langsung berkaitan dengan kulitas produk yang diproduksi perusahaan. Lingkungan yang bersih, nyaman dan tidak berisik akan membuat karyawan lebih betah dan berkonsentrasi untuk melaksanakan pekerjaannya. Oleh sebab itu maka sebaiknya perusahaan membuat ruangan terpisah per bagian produksi agar suasana lebih nyaman. Selain itu penataan layout tempat produksi harus dipehatikan lebih baik agar kinerja produksi dapat berjalan lebih efektif dan efisien.

\section{SIMPULAN DAN SARAN}

Berdasarkan hasil penelitian yang dilakukan pada UD. Cipta Lestari, maka dapat disimpulkan bahwa pengendalian proses produksi yang dilakukan di perusahaan sudah berjalan dengan baik namun masih belum optimal. Berdasarkan analisis data menggunakan peta kendali, maka diketahui bahwa persebaran data kecacatan produk masih berada pada batas yang wajar, sehingga dapat dikatakan bahwa pengendalian kualitas diperusahaan sudah berjalan dengan baik. Sedangkan apabila dilihat dari analisis biaya kualitas perusahaan pada tahun 2018 , biaya kualitas aktual yang harus dikelurkan perusahaan lebih besar bila 
dibandingkan dengan biaya kualitas optimum hal ini berarti sistem pengendalian kualitas yang dilakukan pada perusahaan belum dapat mencapai tingkat optimal.

Saran yang dapat diberikan kepada perusahaan yaitu, perusahaan perlu untuk memperhatikan faktor-faktor penyebab terjadinya penyimpangan pada produk, adapun hal-hal yang disarankan untuk dapat mengurangi permasalahan dalam proses produksi antara lain: (1) Manusia, Perusahaan perlu mengadakan pelatihan ataupun sosialisasi kepada seluruh karyawannya secara rutin, guna meningkatkan pemahaman karyawan mengenai proses produksi yang baik, efisien serta berkualitas. (2) Metode, Perusahaan sebaiknya memberikan instruksi kerja dengan jelas kepada karyawannya selama proses produksi berlangsung. (3) Mesin, Perusahaan sebaiknya lebih memberikan perhatian kepada mesin-mesin yang ada dan lebih rajin untuk melakukan pembersihan setiap sebelum dan sesudah menggunakan mesin tersebut. (4) Lingkungan, Perusahaan sebaiknya dapat menciptakan lingkungan kerja yang nyaman dan bersih agar konsentrasi serta semangat kerja karywan dapat meningkat.

\section{REFERENSI}

Alkubaisi, M. (2013). Statistical Quality Control (Sqc) And Six Sigma Methodology: An Application Of X-Bar Chart On Kuwait Petroleum Company. International Journal of Business Administration, 4(3). Http://Doi.Org/10.5430/Ijba.V4n3p61

Assauri, Sofyan. (2008). Manajemen Pemasaran. Jakarta: Rajawali Press.

Bakhtiar, S., Tahir, Tahir., dan Hasni, Ria Asysyfa. (2013). Analisa Pengendalian Kualitas Dengan Menggunakan Metode Statistical Quality Control (SQC) (Studi kasus : pada UD. Mestika Tapaktuan). Malikussaleh Industrial Engineering Journal Vol.2 No.1 29-36 
I Gusti Ayu Andika Harum Sari dan Gede Mertha Sudiartha, Pengendalian Kualitas Pro...

Banker, K., Patel, A., \& Patel, D. (2014). Implementation Of Statistical Quality Control ( S . Q . C .) In Welded Stainless Steel Pipe Manufacturing Industry.International Journal of Research in Engineering and Technolog, 2319-2322.

Bhosale, S. D., Shilwant, S. C., \& Patil, S. R. (2013). Quality Improvement In Manufacturing Processes Using Sqc Tools. International Journal Of Engineering Research And Applications, 3(3), 832-837.

Busyairi, Ahmad. (2017). Statistical Quality Control (Sqc) Dalam Menentukan Tingkat Kecacatan Produk Pada Industri Kerajinan Tangan Batik Sasambo "Jaya Abadi" Di Desa Pringgasela - Lombok Timur. Journal Ilmiah Rinjani_Universitas Gunung Rinjani, Vol. 5 No. 1

Devani, V., \& Wahyuni, F. (2016). Pengendalian Kualitas Kertas Dengan Menggunakan Statistical Process Control Di Paper Machine 3. Jurnal Teknik Industri Uin Sultan Syahrir Kasim Riau, Vol.15(No.2), 87-93.

Elmas, M. S. H. (2017). Pengendalian Kualitas Dengan Menggunakan Metode Statistical Quality Control (Sqc) Untuk Meminimumkan Produk Gagal Pada Toko Roti Barokah Bakery. Penelitian Ilmu Ekonomi Wiga, 7(3), 15-22.

Garrison, Ray H, Noreen dan Brewer.(2006). Akuntansi Manajerial Edisi 11. Jakarta: Salemba Empat

Godina, R., Matias, J. C. O., \& Azevedo, S. G. (2016). Quality Improvement With Statistical Process Control In The Automotive Industry. International Journal Of Industrial Engineering And Management (Ijiem), 7(1), 1-8. Retrieved From Www.Iim.Ftn.Uns.Ac.Rs/Ijiem_Journal.Php

Halim Lim, S. A., Antony, J., Arshed, N., \& Albliwi, S. (2017). A Systematic Review Of Statistical Process Control Implementation In The Food Manufacturing Industry. Total Quality Management And Business Excellence,28(1-2), 176189.Http://Doi.Org/10.1080/14783363.2015.1050181

Hansen, Don R dan Maryanne M.Mowen.(2009).Akuntansi Manajemen Jilid 2. Jakarta: Erlangga.

Harpreet, E., Oberoi, S., Parmar, M., Kaur, H., \& Mehra, R. (2016). Spc ( Statistical Process Control ): A Quality Control Technique For Confirmation To Ability Of Process. International Research Journal Of Engineering And Technology, 3(6), 666-672. Retrieved Https://Www.Irjet.Net/Archives/V3/I6/Irjet-V3i6124.Pdf 
Heizer, Jay dan Barry Render.(2015).Manajemen Operasi: Manajemen Keberlangsungan dan Rantai Pasokan, Edisi Kesebelas. Jakarta: Salemba Empat

Kemit, N., Suamba, I. K., \& Yudhari, I. D. A. S. (2016). Pengendalian Mutu Kopi Luwak Pada Perusahaan Cv Sari Alam Pegunungan Di Kabupaten Bangli. EJurnal Agribisnis Dan Agrowisata, 5(3), 509-516.

Madanhire, I., \& Mbohwa, C. (2016). Application Of Statistical Process Control (Spc) In Manufacturing Industry In A Developing Country. Procedia Cirp, 40, 580-583. Http://Doi.Org/10.1016/J.Procir.2016.01.137

Marire, M. I., Ekpere, B., \& Ngozi, N. (2014). The Problems Of Quality Control In The Manufacturing Sector A Study Of Nigeria Breweries Plc, Enugu. Iosr Journal Of Business And Management, 16(12, 2278-387X), 96-107.

Mengesha, Y., Singh, A. P., \& Yimer, W. (2013). Yonatan Mengesha Wassihun Yimer Quality Improvement Using Statistical Process Control Tools In Glass Bottles Manufacturing. International Journal for Quality Research, 7(October 2012), 107-126.

Mostafaeipour, A., Sedaghat, A., \& Al, E. (2012). The Use Of Statistical Process Control Technique In The Ceramic Tile Manufacturing: A Case Study. International Journal Of Applied Information Systems (Ijais) -, 2(5), 14-19. Http://Doi.Org/10.1080/Jmf.12.3.209.211

Mulyadi. (2014). Akuntansi Biaya. Edisi 5. Yogyakarta: STIM-YKPN.

Ningsih, Ni Kadek Ayu., Suamba, I Ketut., dan Sarjana, I Dewa Gede Raka. (2016). Pengawasan Mutu pada Pengolahan Dodol Salak di CV Duta Gunung Salak. E-Jurnal Agribisnis dan Agrowisata. Vol. 5, No. 2,

Ogedengbe, T. I., R. K. Apalowo and A. B. Akinde. (2016). Application of Statistical Quality Control for Investigating Process Stability and Control in an Electric Wire Industry. International Journal of Science and Technology, Volume 5 No. 3

Omar, M. H. (2010). Statistical Process Control Charts For Measuring Rating Consistency Over Time. Journal Of Educational Measurement, 47(1), 1835. Http://Doi.Org/10.1111/J.1745-3984.2009.00097.X

Patidar, G., \& Singhverma, D. (2015). Case Study Of Process Variation In A Steel Tube Manufacturing Industry. International Journal for Scientific Research \& Development, 3(04), 3296-3300. 
I Gusti Ayu Andika Harum Sari dan Gede Mertha Sudiartha, Pengendalian Kualitas Pro...

Rachman, R. (2017). Pengendalian Kualitas Produk Di Industri Garment Dengan Menggunakan Statistical Procces Control ( Spc ). Jurnal Informatika, 4(2), 174-182. Retrieved From Http://Ejournal.Bsi.Ac.Id/Ejurnal/Index.Php/Ji/Article/View/1970/Pdf \%0a

Rahmandinata, Farid., Hamid, Liswar., dan Marpaung, Rio. (2015). Pengendalian Mutu Produksi Ikan Salai Patin Di Sentra Pengolahan Pasca Panen Dengan Metode Sqc (Statistik Quality Control)Di Desa Koto Mesjid Kecamatan Koto Kampar Kabupaten Kampar Provinsi Riau. Jom FEKON Vol. 2 No. 2

Ratna Sari, Ni Kadek., dan Purnawati, Ni Ketut. (2018). Analisis Pengendalian Kualitas Proses Produksi Pie Susu Pada Perusahaan Pie Susu Barong Di Kota Denpasar. E-Jurnal Manajemen Unud, Vol. 7, No. 3. DOI: https://doi.org/10.24843/EJMUNUD.2018.v7.i03.p016

Ria Asysyfa Hasni, S. (2013). Analisa Pengendalian Kualitas Dengan Menggunakan Metode Statistical Quality Control (Sqc). Malikussaleh Industrial Engineering Journal, 2(1), 29-36. Http://Doi.Org/10.1002/Eji.201445193

Rizal, Afrul., dan Iskandar. (2017). Analisis Pengendalian Kualitas Rokok Pada Tahap Proses Packer Dengan Metode Statistical Quality Control (Sqc). JPTM. Volume 06 Nomor 01, 22-27

Runtuwene, V. E., Massie, J. D. D., \& Tumewu, F. (N.D.). Statistik Di Pt Massindo Sinar Pratama Manado Quality Control Analysis Using Statistical Quality Control At Pt Massindo, 5(2), 2516-2525.

Rusdianto, Andrew Setiawan., Novijanto, Noer., dan Alihsany, Rosy. (2011), Penerapan Statistical Quality Control (Sqc) Pada Pengolahan Kopi Robusta Cara Semi Basah. J Agrotek, 5(2) : 1-10

Saragih, J. R. (2016). Produksi Kopi Arabika Spesialti Sumatera Utara: Analisis Sosial Ekonomi, Ekologi, Dan Kebijakan Pemerintah Daerah. Prosiding Seminar Ilmiah Dies Natalis Ke-60 Universitas Sumatera Utara, 1-11. Http://Doi.Org/10.31227/Osf.Io/Y96fb

Sidartawan, R. (2014). Analisa Pengendalian Proses Produksi Snack Menggunakan Metod Statistical Process Contorol (Spc). Assembly Automation, 7(2), 10-14.

Suryaningrat, Ida Bagus., Novijianto,Noer., dan Faidah, Nur. 2015. Penerapan Metode Statistical Quality Control(SQC) Pada Pengolahan Biji Kakao. Jurnal Agroteknologi, Vol. 09 No. 01 
E-Jurnal Manajemen, Vol. 8, No. 4, 2019: 2495 - 2523

Sutrisno.(2012). Manajemen Keuangan Teori, Konsep dan Aplikasi. Yogyakarta: EKONISIA.

Tanjong, S. D. (2013). Implementasi Pengendalian Kualitas Dengan Metode Statistik Pada Pabrik Spareparts Cv Victory Metallurgy Sidoarjo. Jurnal Manajemen Bisnis Dan Ekonomika, 5(1), 1-10.

Weckenmann, A., Akkasoglu, G., \& Werner, T. (2015). Quality Management History And Trends. Tqm Journal, 27(3), 281-293. Http://Doi.Org/10.1108/Tqm-11-2013-0125

Widiaswanti, Ernaning. (2016). Penggunaan Metode Statistical Quality Control (Sqc) Untuk Pengendalian Kualitas Produk. Industri Inovatif Vol. 4, No. 2, $6-12$ 